\title{
JUSTIFYING SUPRANATIONAL RESPONSES to the ANTI-CONSTITUtionalist Challenge APPLYING Liberal MUlTICULTURALISM AS A BACKGROUND THEORY
}

Zsolt Körtvélyesi and Balázs Majtényi

(Accepted Manuscript)

October 2020

\begin{abstract}
The EU is bound to respect the national identities of Member States. States might, at occasions, define their national identities in ways that breach inclusive constitutional values (e.g. equality) protected under TEU Article 2. The assumption behind the recognition of diverse constitutional identities is the peaceful coexistence of both, which is challenged by illiberal national developments. Instead, we see a zero-sum game between the constitutional recognition of exclusive values (e.g. dominant ethnicity or religion) and inclusive constitutional values; every gain by the proponents of emergent authoritarianism translates to a loss on the side of constitutional democracy. While exclusive norms appear in virtually every constitutional system, a critical mass of exclusive values can lead to the hollowing out of a democratic order, both on the national and on the supranational level. To try to draw the line where this shift happens, we are relying on the limits of toleration, and recognition, of exclusive norms and identity elements of minority communities in liberal theories of multiculturalism (e.g. Raz, Taylor, Kymlicka). We think that the case of illiberal minorities raise structurally similar theoretical questions, insights, and experiences than the dilemma defined above, the challenge of illiberal Member States undermining EU fundamental values.
\end{abstract}

This article was conducted within the scope of the H2020 project Democratic Efficacy and the Varieties of Populism in Europe (DEMOS) and was funded by the European Commission under the Grant agreement 822590. Any dissemination of results here presented reflects only the authors' views. The Agency is not responsible for any use that may be made of the information it contains. 


\section{Introduction}

In this article, we present a normative framework that is applicable to the dilemma raised by the anti-constitutionalist challenge in the European Union. We propose using basic tenets of liberal theories of multiculturalist politics as a background theory. Our central claim in this article is that there are valuable lessons to be learnt from the parallel drawn between the 'illiberal challenge' in the EU and the problem posed by illiberal minorities in liberal multicultural states.

The key challenge the European Union faces is framed in this article as 'anticonstitutionalism'. We deliberately opt for this term instead of 'illiberalism', 'populism', 'authoritarianism' or other labels, because we think that this captures best the difficulty that public law faces in illiberal Member States, e.g., Hungary. Such states reject pluralism, often along with equal dignity. As a result, they end up undermining the democratic rule of law and human rights, the foundations upon which constitutionalism rests. ${ }^{1}$ The challenge parallels the classical liberal dilemma concerning the limits of tolerance. Our starting assumption is that liberal multiculturalism, the theoretical approach we rely on in this article, offers clues for demarcation.

We agree with those who think that the institutions of liberal democracies-and inclusive constitutional values-are worthy of protection. As János Kis states: 'The values of liberal democracy are true and attractive ideas. ${ }^{2}$ The most persuasive argument for this statement today might be to look at its recent alternatives, like left- or right-wing illiberal regimes outside and inside the European Union, e.g., the illiberal systems of Venezuela or Hungary. ${ }^{3}$ Further, we agree with those proponents of multiculturalism who argue for the importance of the equal recognition of individual and group identities, and hence the need for the politics of multiculturalism, because we think a society blind to difference is, a discriminatory society.

In the following pages we first sketch a legal framework based on key provisions of the Treaty on European Union (TEU) and present possible interpretations of their relationship. Second, we seek to understand this relationship through a reading of the underlying theoretical foundation based on the distinction between exclusive and inclusive constitutional values. The hypothesis that underlies our discussion is that there is a zero-sum game between the constitutional recognition of exclusive constitutional values (ethnicity, religion, etc., of the dominant population) and inclusive constitutional values (e.g., equality, human dignity, human rights). ${ }^{4}$ This does not mean, however, that a certain level of exclusive values cannot be tolerated. It is empirically true that liberal democracies maintain a commitment to some exclusive values (favouring certain cultures in the form of language, ethnicity, religion). This raises the question of the extent to which this can be justified. We argue that some level of

\footnotetext{
${ }^{1}$ This also means that we do not disagree with other labels, we just think 'anti-constitutionalism' is particularly useful for the context of this article. We find the descriptions and explanations going back to Anti-Enlightenment sentiments and the category of electoral authoritarianism particularly applicable, in a broader sweep. See Zeev Sternhell, Les anti-Lumières: Une tradition du XVII' siècle à la guerre froide (Fayard, 2006) (in English: The AntiEnlightenment Tradition (Yale Oxford University Press, 2009); and Andreas Schedler, The Politics of Uncertainty: Sustaining and Subverting Electoral Authoritarianism (Oxford University Press, New York, 2013).

2 János Kis, Alkotmányos demokrácia [Constutional Democracy] (Kalligram, Budapest, 2019), 14.

${ }^{3}$ lbid.

${ }^{4}$ For more details, see Zsolt Körtvélyesi and Balázs Majtényi, 'Game of Values: The Threat of Exclusive Constitutional Identity, the EU and Hungary,' German Law Journal 18, no. 7 (2017): 1721-44.
} 
toleration for exclusive values can be normatively acceptable. We argue that multiculturalist theories can provide useful insights for conceptualising conflicts between constitutional values.

In this article we briefly discuss how our approach relates to legal pluralist discussions, maintaining that-including multiculturalist accounts -it enriches the pluralism debate. More specifically, we think that reliance on liberal multiculturalism strengthens the normative layer in that it values the recognition of group identities as a means to individual well-being and dignity, while it presents homogenisation as an inherent loss that should be justified.

Finally, we assess the possible implications of applying this approach. The article concludes that multiculturalist accounts justify liberal interference under certain circumstances. Such accounts can help conceptualise the enforcement of Article 2 TEU values and their relationship to the protection of Member State national identities in Article 4(2) as well as assessments under Article 7 TEU.

\section{The Dilemma}

In line with Article 4(2) TEU, the EU is bound to respect the national identity of Member States 'inherent in their fundamental structures, political and constitutional, inclusive of regional and local self-government. ${ }^{5}$ Besides Article $4(2)$, the $6^{\text {th }}$ recital of the Preamble also mentions respect for history, culture, and traditions of Member States. These provisions of the Treaty protect not only constitutional structures that express constitutional identity, but also the cultural and historical roots of national identity. ${ }^{6}$ Thus, just like their constitutional structure, Member States can define their national identity in differing ways, including approaches that may breach inclusive constitutional values like equality or dignity. Even so, the implications of transforming the Member States' national identities raise legitimate concerns for inclusive values that are labelled as fundamental and protected as such by Article 2:

The Union is founded on the values of respect for human dignity, freedom, democracy, equality, the rule of law and respect for human rights, including the rights of persons belonging to minorities. [...]

It is important to note that there is no established hierarchy in the text of the Treaty between Article 4(2) and Article 2. The codification of what is now Article 2 has been an important step in making certain background assumptions of European integration and cooperation fully explicit. The Article lists the content of key commitments, the lack of which would undermine the functioning of the EU. ${ }^{7}$ In summary, Article 2 values as a whole are essential for the

\footnotetext{
5 'The Union shall respect the equality of Member States before the Treaties as well as their national identities, inherent in their fundamental structures, political and constitutional, inclusive of regional and local selfgovernment.' Article 4(2) TEU.

${ }^{6}$ Leonard F. M. Besselink, 'National and Constitutional Identity before and after Lisbon,' Utrecht Law Review 6 (2010): 43.

${ }^{7}$ Kochenov ('The Acquis and Its Principles...,' 24-25 and 26) warns against "too much" focus on values, i.e., an overly demanding value-based scrutiny could undermine the logic of EU law prominently not based on (direct) reciprocity. Article 2 in fact underlines the background assumptions of mutual trust and general reciprocity in that all Member States are presumed to share a basic commitment to Article 2 values - the point we are making above.
} 
functioning of the EU. ${ }^{8}$ The Article lists the fundamental values of the European Union, including the value of human rights protection that is further specified in Article 6(3) with reference to the ECHR as resulting 'from the constitutional traditions common to the Member States' (emphasis added). ${ }^{9}$ Again, Member State societies should share these values. In addition, Member States should engage in 'sincere cooperation' actively ensuring membership obligations and avoid undermining integration under Article $4(3) .{ }^{10}$ Pluralism is also mentioned in Article 2, the second sentence of which states that the values quoted earlier 'are common to the Member States in a society in which pluralism, non-discrimination, tolerance, justice, solidarity and equality between women and men prevail.' Pluralism is also protected on another level. Integration is limited and is certainly not all-encompassing as stressed in Articles 4(1), ${ }^{11} 5(2),{ }^{12}$ and partly 4(2), ensuring leeway in non-covered areas.

As is the case with legal rules, cases of (alleged) violations provide the true test for the workability of this framework. The Hungarian and Polish cases should be enough to demonstrate that the assumption of peaceful convergence has been debunked. As such we are basically forced to confront the question of how to conceptualise the connection between Articles 2 and 4(2). As a rudimentary classification, we can identify two logical endpoints.

What we could call the universalist reading maintains the primacy of Article 2 under all circumstances. Here Article 4(2) allows any deviation-regarding the means or other technicalities - only within the field marked by Article 2, rendering the respect for national identity to little more than a decorative detail. ${ }^{13}$ The other, which we now call the relativist (or strong pluralist) reading, assures the primacy of Article 4(2). Under the latter reading Article 2 serves as a menu, and Member States (the customers) are relatively free to define their diet by vetoing particular items that would somehow clash with respect for their national identity. To make this more plausible, a formal interpretation of democracy and the rule of law should be maintained, but in terms of actual conceptualisation wide variation is allowed on the national level.

Under the first reading, Article 4(2) may only work within the boundaries set by Article 2; after all, this is why they are cast as foundational values. This is supported by the wording ('The Union is founded on...') as well as the history and will behind the text. What this description

\footnotetext{
8 The values listed are also fundamental because, crucially, Article 2 does not refer to market economy, economic integration, or a common market. Reference to the 'internal market' in Article 3(3) comes only after an 'ever closer union' in Article 1, the listing of values in Article 2, 'peace' in Article 3(1), and the 'area of freedom, security and justice' in Article 3(2). This confirms the historical account that the common market should be seen as the economic-practical means toward historical-political goals-a point beyond the scope of the present article. For the (corrective) historical account, see Gráinne de Búrca, 'The Road Not Taken: The European Union as a Global Human Rights Actor,' American Journal of International Law 105 (2011): 649.

9 'Fundamental rights, as guaranteed by the European Convention for the Protection of Human Rights and Fundamental Freedoms and as they result from the constitutional traditions common to the Member States, shall constitute general principles of the Union's law.' Article 6(3).

10 'Pursuant to the principle of sincere cooperation, the Union and the Member States shall, in full mutual respect, assist each other in carrying out tasks which flow from the Treaties.' Article 4(3).

11 'In accordance with Article 5, competences not conferred upon the Union in the Treaties remain with the Member States.' Article 4(1).

12 'Under the principle of conferral, the Union shall act only within the limits of the competences conferred upon it by the Member States in the Treaties to attain the objectives set out therein. Competences not conferred upon the Union in the Treaties remain with the Member States.' Article 5(2).

${ }^{13}$ We have noted earlier that the case law of the clause in question does little to repudiate this reading. See no. 12 above.
} 
fails to capture, however, is that the exact meaning of these values remains contested. ${ }^{14}$ When defining their content, interpretation will necessarily rely on existing practices in EU Member States and would face the same dilemma of having to draw the line somewhere between permissible and impermissible state practices. Accordingly, these values are not items on a menu, and selectivity is not possible. This approach is partly due to the fact that textual interpretation of the Article does not support such a reading. It maintains that all of the values listed should be read together, in light of an all-encompassing moral framework, ${ }^{15}$ e.g., under the mainstream position holding each of them is conceptually underpinned by respect for human dignity, ${ }^{16}$ where violation of one value goes against the entire framework.

Intermediary readings between the two logical endpoints are also available. For example, we can adopt an equalising or pluralist reading: the two clauses are on the same level, without (clear) hierarchy. However, to make this a workable approach we have to provide a background theory on how to resolve possible conflicts on a case-by-case basis. Inherent in several readings (e.g., that cited above on undermining the functioning of the $\mathrm{EU}^{17}$ ) is a functionalist philosophy: the goal of Article 2 is to guarantee the foundational values without which the EU cannot function; and whatever does not undermine integration is tolerated under Article 4(2). Even so, functionalism is not self-explanatory and self-validating. We need a normative approach that sets out the goals of integration in relation to which we can tell which functions we seek to protect. What is clear under these readings is that recognition in Article 4(2) comes with limits. It is not a blank check, and we need a coherent framework to decide when divergence is permissible.

Another field where the same tension has erupted is the debate on (constitutional) pluralism. The central question this field grapples with falls within the parameters of our inquiry: can a normative core justify limiting pluralism and how far can this core extend? In Joseph H.H. Weiler's words: any constitutional regime has 'both the pluralist and hierarchical combinedthough one can have endless debates on the appropriate dosages of each.' ${ }^{18}$ As a matter of descriptive pluralism, the EU's Article 2 embodies this normative core that should be 'common' to all Member States, as we have seen. Normatively, without a common core, pluralism would fall back to radical pluralism-an unappealing scenario for European

\footnotetext{
${ }^{14}$ On 'essentially contested concepts', see Walter Bryce Gallie, 'Essentially Contested Concepts,' Proceedings of the Aristotelian Society 56 (1955-1956): 167-98. For a recent account on democracy specifically, see John S. Dryzek, 'Can There Be a Human Right to an Essentially Contested Concept? The Case of Democracy,' Journal of Politics 78, No. 2 (2016): 357-67.

15 See, e.g., Dworkin's arguments: Ronald Dworkin, Justice for Hedgehogs (Oxford University Press, Cambridge/London, 2011) and, earlier, Ronald Dworkin, Freedom's Law: The Moral Reading of the American Constitution (Oxford University Press, New York, 1996).

${ }^{16}$ Catherine Dupré, Dignity, Democracy, Civilisation, Liverpool Law Review 33, 263-280 (2012). For an overview, see Alexandra Timmer, Balázs Majtényi, Katharina Häusler, and Orsolya Salát, EU Human rights, democracy and rule of law: from concepts to practice, (2014) FRAME Deliverable 3.2, available at <http://www.fp7frame.eu/wp-content/uploads/2016/08/10-Deliverable-3.2.pdf.>

${ }^{17}$ To cite one such phrase from the literature: 'the failure to enforce the values of the Union will most likely result in the undermining of the core acquis going to the heart of EU law and is not solely confined to the internal market'. Kochenov, 'The Acquis and Its Principles...,' 10.

${ }_{18}$ Joseph H. H. Weiler, 'Prologue: Global and Pluralist Constitutionalism - Some Doubts,' in The Worlds of European Constitutionalism, eds. Gráinne de Búrca and Joseph H. H. Weiler (Cambridge University Press, New York, 2011), 17.
} 
integration. Mattias Kumm describes this as a realm 'where actors of each legal order proceed without systemic regard for the coherence of the whole.'19

It is clear that pluralism also needs 'a doctrinal framework that defines the conditions under which either institutionalized civil disobedience or constitution-based conscientious objection are justified.' ${ }^{20}$ For Kumm, 'Constitutionalism establishes a framework of principles that provide the grounds and limits of legal authority of any legal order within the liberal democratic tradition. ${ }^{21}$ One can ask what happens with legal orders outside this tradition. ${ }^{22}$ Matej Avbelj argues that 'any Member State which in defence of its own autonomy, invokes the pluralist structure of the Union, can only do so after it has given effect to pluralism within its own constitutional polity. ${ }^{23}$ In a similar vein, pluralism on the European level presupposes pluralism on the national level, just as pluralism in a liberal multicultural state presupposes pluralism on the level of the territorial units (e.g., federated member states) of the state.

In a sense, our overview runs parallel to these pluralist analyses. Multiculturalist theories might be more in line with increasingly permissive pluralist approaches in that they acknowledge the worth of giving due recognition to community values, even in the case of non-liberal entities. But these theories also stop short of granting such regimes a free hand.

To this point we have discussed the question of how the tension can be tackled conceptually. However, there is also an institutional and procedural question. Article 7 TEU is about determining 'the existence of a serious and persistent breach by a Member State of the values referred to in Article $2{ }^{\prime}{ }^{24}$ This procedure could, in principle, lead to the suspension of 'certain of the rights deriving from the application of the Treaties to the Member State in question, including the voting rights of the representative of the government of that Member State in the Council,' ${ }^{25}$ if a breach of the fundamental values of the EU is established. As events in Hungary, to a degree Romania, and lately in Poland have given us clear cases of breaching the rule of law-all the while the workability of Article 7 is very much in doubt ${ }^{26}$-most

\footnotetext{
${ }^{19}$ Mattias Kumm, 'The Moral Point of Constitutional Pluralism Defining the Domain of Legitimate Institutional Civil Disobedience and Conscentious Objection,' in Philosophical Foundations of European Union Law, eds. Julie Dickson and Pavlos Eleftheriadis (Oxford University Press, Oxford, 2012), 217.

${ }^{20}$ Kumm, 'The Moral Point...,' 238.

${ }^{21}$ Kumm, 'The Moral Point...,' 242.

22 The type of pluralism that Kumm puts forward makes it impossible to conceptualise pluralism as encompassing both liberal and non-liberal, constitutionalist and anti-constitutionalist legal systems. See his discussion on the monist features of his pluralism in Kumm, 'The Moral Point...,' 244-45. '[T] he world of public law is imagined as constituted and held together by a shared commitment to constitutional principles' (Ibid.), so a rejection of these principles pushes one out of this 'world of public law'.

${ }^{23}$ Matej Avbelj, 'Pluralism and Systemic Defiance in the EU,' in The Enforcement of EU Law and Values: Ensuring Member States' Compliance, eds. Jakab, András, and Dimitry Kochenov (Oxford University Press, New York, 2017), 57. Also: '[...] pluralism cannot be defied pluralistically. A pluralist European integration assumes that its Member States are well-ordered societies. After all, this is what the entire process of pre-accession conditionality is dedicated to. A pluralist European integration can therefore only exist if its Member States are ab initio committed to pluralism.' Ibid. at 56-57.

${ }^{24}$ Article 7(2) TEU.

${ }^{25}$ Article 7(3) TEU

${ }^{26}$ See debate on whether Article 7 is a 'nuclear option'. The 2011 edition of the Craig-de Búrca book declares 'despite the symbolism of Article 7 TEU, and a number of attempts which have been made by the European Parliament to instigate its application, it seems unlikely to have any significant application in practice.' Paul Craig, and Gráinne de Búrca, EU Law. Text, Cases, and Materials, 5 ${ }^{\text {th }}$ ed. (Oxford University Press, New York, 2011), 390.
} 
commentators have focused on the question of 'how' ${ }^{27}$ Proposals have been prepared for rendering Article 7 workable, ${ }^{28}$ for reforming the procedure, ${ }^{29}$ or for circumventing it altogether. ${ }^{30}$ Instead of revisiting this debate, we focus on the conceptualisation of the abovementioned values and their relationship to pluralism-most notably to Member State divergence-and the question of justifying the override of Member State commitments in the case of conflict. ${ }^{31}$

Before we present our analogy and point out how multiculturalist readings show important parallels with constitutional practice-and thus provide insights into a possible approach to reconcile the conflict arising from variation and establish the limits of recognising diversitywe first need to differentiate between two sets of values: exclusivity and inclusivity. The distinction is important in understanding where the dilemma originates and where justifications for liberal interference are more likely to succeed.

\section{A Clash of Constitutional Values}

Constitutional values refer to abstract ethical norms that are binding; their ultimate goal is the interpretation of constitutional documents. ${ }^{32}$ National identities and values are not identical, but specific values establish the core of a shared national identity. ${ }^{33}$ In our interpretation inclusive constitutional values are able to integrate the interests of all members of a political community: they treat all members as morally equal and as a result strengthen constitutional democracy. Exclusive constitutional values, however, protect only the ethnic, cultural, political, religious, and other identity elements of one or more dominant groups within a society-usually the identity elements of the majority population. They question the equality

\footnotetext{
${ }^{27}$ For an overview of seven key proposals from systemic infringement procedures to reverse Solange, see Dimitry Kochenov, 'The Acquis and Its Principles. The Enforcement of the 'Law' versus the Enforcement of 'Values' in the EU,' in The Enforcement of EU Law and Values: Ensuring Member States' Compliance, eds. Jakab, András, and Dimitry Kochenov (Oxford University Press, Oxford, 2017), 9-27.

${ }^{28} \mathrm{Kim}$ Lane Scheppele proposed handling the Hungarian and Polish cases jointly, ruling out the other country's veto in each country's case. Kim Lane Scheppele, 'Can Poland be Sanctioned by the EU?: Not Unless Hungary is Sanctioned Too,' Verfassungsblog, October 24, 2016, <https://verfassungsblog.de/can-poland-be-sanctionedby-the-eu-not-unless-hungary-is-sanctioned-too/>.

${ }^{29}$ Albeit not a genuine reform, but an addition on the part of the Commission: the introduction of a 'pre-Article 7 ' procedure, a rule of law mechanism. European Commission, 'A New EU Framework to Strengthen the Rule of Law,' Strasbourg, 11 March 2014, COM(2014) 158 final.

${ }^{30}$ Reverse Solange: Armin von Bogdandy, Matthias Kottmann, Carlino Antpöhler, Johanna Dickschen, Simon Hentrei, and Maja Smrkolj, 'Reverse Solange - Protecting the Essence of Fundamental Rights Against EU Member States,' Common Market Law Review 49 (2012): 489-520; systemic infringement: Kim Lane Scheppele, 'Enforcing the Basic Principle of EU Law through Systemic Infringement Procedures,' in Reinforcing Rule of Law Oversight in the European Union, eds. Carlos Closa and Dimitry Kochenov (Cambridge University Press, Cambridge, 2016).

${ }^{31}$ In this paper we take it for granted that Article 2 values have a widely accepted meaning as exemplified by the broad consensus over violations in the cases of Hungary and Poland. We agree, however, that enforcing values (as the Treaty calls them) is of a different nature than the day-to-day examination of acquis compliance. '[T]he enforcement of values is a different matter compared with the enforcement of the acquis sensu stricto.' Kochenov, 'The Acquis and Its Principles...,' 26. See also the discussion in Craig and de Búrca, EU Law, 375-77, on the conflict of values as opposed to conflict of (lower level) norms.

${ }^{32}$ For defining values, see, e.g., Dennis Davis, Alan Richter, and Cheryl Saunders, 'Introduction,' in An Inquiry into the Existence of Global Values: Through the Lens of Comparative Constitutional Law, eds. Dennis Davis, Alan Richter and Cheryl Saunders (Hart, London, 2015); Pierre Schlag, 'Values,' Yale Journal of Law \& Humanities 6 (1994): 219.

${ }^{33}$ Schlag, 'Values,' 221.
} 
of certain members of the community, reaffirming pre-existing inequalities and creating new ones, which can ultimately undermine the democratic order. ${ }^{34}$ That being said, there is a level of tolerance in a constitutional democracy for exclusive values to recognise group identities valuable to the group members, but only when these are outweighed by inclusive values.

While inclusive values seek to cover everyone, exclusive values seek to differentiate and exclude some. Inclusive approaches, along with multicultural theories, seek inclusion to counteract inequalities inherent in 'cultural membership'. ${ }^{35}$ In these theories, the state is never fully neutral, thanks to its majority biases. In this game every gain by the proponents of emergent authoritarianism translates to a loss on the side of constitutional democracy and the resulting inequalities need to be compensated for. However, accommodation of differences is limited and is only legitimate to the extent that it does not protect oppressive practices. Denial of recognising oppressive practices can in certain cases reduce pluralism (and might seem exclusive on the surface) but overall, such denials are inclusive, for they enforce equal membership. In the EU, Member States can and do in fact question the inclusive values of Article 2 TEU with reference to protecting their national identities. The EU is now faced with the dilemma of how far Member States can extend this right while still retaining their Union membership.

In the game of values, every gain by the proponents of emergent authoritarianism translates to a loss for the side of constitutional democracy, hence 'zero-sum'. While the recognition of both inclusive and exclusive values is common to constitutional democracies, we think that asserting a critical mass of exclusive values can lead to the hollowing out of the democratic order, both on national and supranational levels. ${ }^{36}$ What multiculturalist approaches teach us is that some level of toleration for exclusive values is a necessary and legitimate component of a liberal polity recognizing the values of diversity and pluralism, but also that policing the boundary between accommodation and rejection is central to the functioning and legitimacy of the regime. The line might be drawn differently in different polities or with regard to different groups, e.g., indigenous peoples might get more leeway than subnational units in a federation, but the underlying dilemma follows the same logic.

A democratic political community is considered inclusive when it protects vulnerable minority identities and allows for said minorities to consider themselves part of the given political community. However, if a constitution one-sidedly favours the values and preferences of dominant groups, it does not fulfil the integrative function expected of democratic constitutions. In the latter case the state does not promise to take into account the interests of all citizens equally. As Kymlicka argues, 'some self-government rights and polyethnic rights are consistent with, and indeed required by, liberal justice'. ${ }^{37}$

Individual and collective minority rights are inclusive to the extent that they seek to make all citizens, including minority members, equal by compensating for their disadvantaged position and protecting them from majority decisions. Some groups are simply disadvantaged in the 'cultural market place' 38 and 'they could be outbid or outvoted on resource and policies' that

\footnotetext{
${ }^{34}$ For an account on how exclusive values can 'disunite a nation,' see the volume Constitution for a Disunited Nation: Hungary's New Fundamental Law, ed. Gábor Attila Tóth (CEU Press, New York/Budapest, 2012).

${ }^{35}$ Kymlicka, 1995: 110.

${ }^{36}$ Körtvélyesi, Majtényi, 'Game of Values’ 1722.

37 Kymlicka, 1995: 108.

${ }^{38}$ Kymlicka, 1995: 109.
} 
would be crucial to the survival of their minority identities. ${ }^{39}$ Of course, minority identities can also include exclusive elements; 'some ethnic and national groups are deeply illiberal, and seek to supress rather than support the liberty of their members.' ${ }^{40}$ For example, the protection of minority practices such as FGM should be considered exclusive because they treat women as inferior and push them into a vulnerable position.

State prioritisation of one or two specific languages inevitably leads to a loss of rights regarding minority languages. Let us take the example of a strong constitutional democracy like Canada. Canada gave constitutional recognition to two European languages (French and English) as official languages at the expense of other, most significantly, Aboriginal languages. What possible scenarios could this situation lead to?

Let us model possible action based on the game between exclusive and inclusive values detailed above. The state could explicitly strengthen the exclusive value of the two languages, e.g., the Parliament could pass an Act prohibiting the official use of Aboriginal languages. Such a step would further weaken the principle of equality. Or the Parliament could decide to strengthen inclusive values and adopt an amendment that gives constitutional recognition to all languages which are spoken in Canada. It could also strengthen the protection of minority languages. These measures would weaken the exclusive character of the two European languages. (We will revisit the example of language protection later in this article through the case of the exclusive language policy of a federated state.) The weakening of inclusive values means domestic and European democratic institutions may become vulnerable.

\section{The Analogy of Liberal Multiculturalism}

Multicultural liberal democracies have, from their beginnings, faced the problem of how to accommodate illiberal minorities and to what extent the recognition of cultural differences can be justified. Liberal theories of multiculturalism (e.g., works of Joseph Raz, Charles Taylor, and Will Kymlicka) have extensively discussed this topic. Obviously, the EU is not a liberal multicultural federal state and Member States are not federated states. Nevertheless, we think that these cases are comparable and raise similar theoretical and practical questions and answers. Insights and experiences gained from one case can provide information about the other.

We argue this analogy is applicable, because based on Raz's triadic typology differentiating between liberal approaches built on toleration, non-discrimination or multiculturalism, ${ }^{41}$ the EU is built on a strong form of the acknowledgment of diversity. It does not simply require toleration of or non-discrimination of national disparities, but actively recognises differences and affirms nation states as bounded communities with varied constitutional cultures. With regards to these elements the EU is similar to a multiculturalist state. This also causes the EU to stretch the boundaries of traditional federalism, ${ }^{42}$ bringing it closer to federalisation driven

\footnotetext{
${ }^{39}$ Kymlicka, 1995: 109.

${ }^{40}$ Kymlicka, 1995: 75.

${ }^{41}$ Joseph Raz, 'Multiculturalism: A Liberal Perspective,' in Joseph Raz: Ethics in the Public Domain: Essays in the Morality of Law and Politics (Oxford University Press, New York, 1995), 172-173.

${ }^{42}$ See typology in Sujit Choudhry and Nathan Hume: 'Federalism, Devolution and Secession: From Classical to Post-conflict Federalism,' in Comparative Constitutional Law, Research Handbooks in Comparative Law Series, eds. Tom Ginsburg and Rosalind Dixon (Elgar, Cheltenham, 2011).
} 
by the constant pressure of substate nationalism - a case where the multiculturalist approach is highly relevant. ${ }^{43}$

Raz at one point calls the EU the 'big brother' of multiculturalism, ${ }^{44}$ or more precisely the big brother of liberal multicultural federal states. Multicultural theories, including those by Kymlicka and Raz, openly acknowledge their reliance on the example of European integration. ${ }^{45}$ Kymlicka seemingly uses integration projects like the European Community and NAFTA as a source of inspiration for his theory. ${ }^{46}$ It can seem like a strange twist to build on theories that dissect an area that these authors took inspiration from in the first place. Yet, their reliance on the European experiment does not mean that there is nothing to be learnt from these multiculturalist experiences. In fact, the presence of these references only underlines the structural similarities we also see and justifies the parallel we draw from the other direction.

The parallel seems especially useful when it comes to discussing which types of national identities presented by Member States are justifiable and compatible with Article 2 TEU. It is important to underline that justification is always needed for limiting the national identity of Member States. As Tamás Győrfi argues: 'We do not expect and cannot demand states to give up part of their authority without justification' ${ }^{47}$ In light of this we need to find a scale to define the extent to which exclusive elements of national identity may be tolerated by the Member States' legal systems.

The dilemmas presented above can be seen as revisiting the old liberal dilemma on universality, pluralism, and the limits of toleration. In Jacob T. Levy's pessimistic phrasing, liberalism either errs on the side of rationalism (universalism) or on the side of relativism. ${ }^{48}$ When interpreting the Treaty on European Union, we can err on the former side with overdemanding uniform standards (Article 2), or on the latter by allowing too much leeway on the national level (Article 4(2)). While we agree with Levy that a theoretically fully satisfying synthesis might not be available, we argue that a workable balance should be struck. Such a balance would maintain core elements (common values) under a principled and constrained standard and secure common ground, the lack of which would undermine integration. However, limitless toleration of anti-pluralism would undermine pluralism and cause serious difficulties in ulterior correction with devastating effects on democracy. ${ }^{49}$

It is at this point that multiculturalist accounts engage with the dilemma in depth. They are willing to concede, if not defeat, but losses along the way, and they forcefully address the dilemmas of group recognition, value conflicts, managing diversity and the limits of toleration.

\footnotetext{
${ }^{43}$ This article does not discuss the literature of federalism, which has otherwise offered important insight into the dilemmas of Article 7, especially regarding the parallels to 'subnational authoritarianism'. See R. Daniel Kelemen, 'Europe's Other Democratic Deficit: National Authoritarianism in Europe's Democratic Union,' Government and Opposition 52, Special Issue 2 (Democracy without Solidarity: Political Dysfunction in Hard Times), (April 2017): 211-38.

44 Joseph Raz, 'Multiculturalism,' Ratio Juris 11, No. 3 (1998): 195.

${ }^{45}$ We would like to thank our anonymous reviewer for highlighting this aspect.

${ }^{46}$ Kymlicka, 1995: 168.

${ }^{47}$ Tamás Győrfi, 'The Legitimacy of the European Human Rights Regime - A View from the United Kingdom,' Global Constitutionalism 8, No. 1 (2019): 128.

${ }^{48}$ For a concise summary, see his concluding chapter, 'Against Synthesis'. Jacob T. Levy, Rationalism, Pluralism, and Freedom (Oxford University Press, New York, 2015), 283-95.

${ }^{49}$ In any case, the EU is not committed to full tolerance. As we have seen (unless we stick to the extreme relativist view) Article 2 does define certain substantive commonalities behind integration.
} 
Raz states 'conflict is endemic to multiculturalism', adding that this is in fact true of all forms of value pluralism. ${ }^{50}$ Levy agrees that this conflict flows from liberty, for it is liberty that 'generates pluralism, which generates norms, norm enforcement, and local power, which limit freedom', even if 'the ability to see freedom in our associational lives and power in the state all too often limits the ability to see power in associations and the possibility of freedom being enhanced by outside intervention-and vice versa. ${ }^{51}$

According to theories of liberal multiculturalism, the protection of group identities strengthens the equal dignity of persons belonging to these groups. With this argument these theories support not only tolerance, but also the recognition of cultural pluralism in a liberal framework. This is consistent with the wording of the Article 2, the second sentence of which declares that fundamental inclusive values of the European Union 'are common to the Member States in a society in which pluralism, non-discrimination, tolerance, justice, solidarity and equality between women and men prevail.' The Article can be understood as defining the 'combined goals' 52 of multiculturalism, recognising diversity and producing/maintaining equality. The multicultural reading of Article 2 is reinforced by the fact that Article 4(2) obliges the EU to live with difference ${ }^{53}$ at the collective level as well, like in a liberal multicultural state.

In line with theories of multiculturalism, values that we call 'inclusive' (e.g., equality, dignity, 'respect for human rights, including the rights of persons belonging to minorities') should be ensured, and the recognition of national identity can come only after. Value pluralism in this liberal framework presumes that 'there is a morality which applies to all the traditions and all the cultures, a morality which bridges the divide between them. ${ }^{54}$ This universal morality defines how different moralities can be compatible in recognised communities to support the equality of various cultural groups. Universalism thus does not translate into cultural superiority: 'At the heart of multiculturalism lies the recognition that universal values are realized in a variety of different ways in different cultures, and that they are all worthy of respect. This... is not to endorse all aspects of any culture. My culture no less than others is flawed. ${ }^{55}$

On the other hand, the protection of national identity with reference to shared history, culture, religion, language, etc., cannot override inclusive constitutional values in this theoretical framework. Raz describes liberal multicultural societies as a 'harmonious coexistence of non-oppressive and tolerant communities'. ${ }^{56}$ Therefore, the ideology's guiding principles are the rejection of oppression and mutual respect between cultural groups, as well as the primacy of inclusive values. However, in multicultural societies the primacy of inclusive values offers some level of tolerance to exclusive values in order to protect valuable group identities. Raz talks about the 'dialectics of pluralism' where incompatible values are not only

\footnotetext{
${ }^{50}$ Raz 1992: 37, labelling this a 'non-utopian' vision of multiculturalism.

51 Levy 2015: 295.

${ }^{52}$ Charles Taylor, 'Interculturalism or multiculturalism?', Philosophy and Social Criticism 38, No. 4-5 (2012): 415.

53 Charles Taylor, 'Living with Difference,' in Debating Democracy's Discontent: Essays on American Politics, Law, and Public Philosophy, eds. Anita L. Allen and Jr Regan Milton C. (Oxford University Press, New York, 1998), 21226.

54 Joseph Raz, 'Moral Change and Social Relativism,' in Engaging Reason: On the Theory of Value and Action (Oxford University Press, New York, 2002), 181.

${ }^{55}$ Raz, 'Multiculturalism,' 204.

${ }^{56}$ Raz, 'Multiculturalism,' 199.
} 
present, but also worthwhile and recognised. ${ }^{57}$ Even if certain aspects seem hard to value and support, there might be reasons to still recognise these cultures: 'even oppressive cultures can give people quite a lot, [so] one should be particularly wary of [campaigns against them]. ${ }^{158}$

Interference with domestic structures will always raise the dilemma of whether intervention is justified or is an affront to the recognition of diversity. Raz lists three types of liberal dilemmas' with multiculturalism: oppression, superiority, and the necessity of a common culture. ${ }^{59}$ Raz stresses that the multiculturalist view he endorses is not 'opposed [to] the change... on the contrary... multiculturalism insists that members of the different groups in a society should be aware of the different cultures in their society, and learn to appreciate their strengths and respect them. This in itself leads to inevitable developments,' the pressure being higher in intolerant cultures. ${ }^{60}$ Like recognition under Article $4(2)$ in the case of the EU, the recognition of diversity in the case of multiculturalism serves a specific goal, 'a concern for the [dignity and] well-being of the members of society. ${ }^{61}$ Recognition remains conditional, resulting in an 'uneasy alliance' that sometimes supports proponents of diversity (like the sovereigntists in the case of the EU), '...while at others turning against them to impose ideals of toleration and mutual respect, or to protect the members of those very cultures against oppression by their own group.' ${ }^{62}$

\section{Possible Implications of the Background Theory}

Weaving together the three lines of our inquiry: Article 2 values are inclusive, but Article $4(2)$ raises the possibility of recognising exclusive values based on Member State choice. Applying the multiculturalist approach summarised above, the decision will imply a loss, while overriding national commitments will require justification. Our question is thus how the multiculturalist approach can help inform this debate.

For example, using the concept of 'nation' in a Member State's constitution is acceptable only if the legal order of the democratic political community respects the equal dignity and wellbeing of every one of its citizens. The lawmaker thus cannot act against the moral equality of citizens and must exhibit equal attention to and respect toward each member of the political community. ${ }^{63}$ Relying on the premodern vision of the political nation that incorporates values influenced by state identity (e.g., faith and fidelity) without regard for the principle of equality (when only the members of a particular social class, e.g., nobility, workers, members of a caste, etc. may belong to the nation) naturally does not fulfil this demand.

If we apply theories of multiculturalism to the institutional framework of the EU, we can state for instance that the Hungarian illiberal regime breaches the value system of the European Union: it builds the country's national identity on the rejection of the primacy of inclusive values. The preamble of the Hungarian Fundamental Law, the 'National Avowal of Faith'

\footnotetext{
${ }^{57}$ Raz, 'Multiculturalism...,' 190.

${ }^{58}$ Raz, 'Multiculturalism...,' 195.

${ }^{59}$ Raz, 'Multiculturalism...,' 174.

60 Raz, 'Multiculturalism,' 191.

${ }^{61}$ Raz, 'Multiculturalism...,' 185; see also Raz, 'Multiculturalism,' 197.

${ }^{62}$ Raz, 'Multiculturalism...,' 183.

63 In Dworkin's wording: 'Political equality [and democracy] requires that political power be distributed so as to confirm the political community's equal concern and respect for all its members.' (emphasis added) Ronald Dworkin, Justice for Hedgehogs (Belknap, 2011), 391.
} 
provides an apt example to prove this point. It fails to mention equality as a value, but offers a list of exclusive values - such as belonging to a Christian church, belonging to the Hungarian ethnic nation, fidelity, faith and love-and along these lines it redefines the national identity of Hungary. ${ }^{64}$ It conveys that members of national or religious minorities are not equally part of the constitutional power, which violates the principle of mutual respect between cultural groups, as well as the primacy of inclusive values on which liberal multiculturalism is built.

As discussed above, a critical mass of exclusive values undermines a legal system's liberal core, i.e., the equal dignity of residents. Therefore, the exclusive values listed in the Hungarian Fundamental Law had a transforming effect on the country's legal system. These exclusive values have made their marks in several areas. They are manifest in the Hungarian government's attacks on the Central European University, the banning of gender studies MA programs in universities, the 'Stop Soros' law targeting human rights NGOs and asylum activists, and the criminalisation of homelessness in order to protect 'cultural values'. The Hungarian case is illustrative in many ways. The vision of the national community and its members is cast in a culturally limited way (full of exclusive elements). Also, actual policies are increasingly defining parts of the population as enemies of the state. Finally, this concept is characterised by a constant search for enemies: according to the most common framing, this can mean foreign agents of an international pro-immigration liberal coalition with links to philanthropist George Soros and mainstream forces in Brussels, etc. ${ }^{65}$

However, references to the protection of Member States' national identity also exist that do not contradict Article 2 in this multicultural interpretation. For instance, there are nonexclusive arguments for Brexit on parliamentary supremacy being incompatible with European supremacies. Győrfi, among others, finds normative arguments for 'the Commonwealth model of judicial review [that] has established a mechanism of human rights protection in which the legislature can disregard or override a court's determination of what a human right requires. 66

Brexit and the Hungarian public law crisis have common features: both are about national identity and self-identification of the people and their values, and both express a longing for stronger sovereignty (or 'taking back control' from the EU). The Brexit campaign exploited the loss of sovereignty by arguing that EU legislation, with the support of the Luxembourg and Strasbourg courts, restricts Member State institutions (i.e., parliaments and courts) and their sovereignty at an unacceptable level. Throughout the Brexit campaign these arguments were obviously mixed with unjustifiably exclusive, xenophobic discourses, e.g., the crusade against immigration. But even in this case, reclaiming the ability to decide nationally on who can enter the country seemed central. ${ }^{67}$

\footnotetext{
${ }^{64}$ Balázs Majtényi, 'The Nation's Will as Trump in the Hungarian Fundamental Law.' In European Yearbook on Human Rights 15, ed. Wolfgang Benedek et al. (Intersentia, Antwerpen/Wien/Graz, 2015), 247-60.

${ }^{65}$ Balázs Majtényi, Ákos Kopper, and Pál Susánszky, 'Constitutional Othering, Ambiguity and Subjective Risks of Mobilisation in Hungary: Examples from the Migration Crisis,' Democratization 26, No. 2 (2019): 173-189.

${ }^{66}$ Tamás Győrfi, 'The legitimacy of the European human rights regime-a view from the United Kingdom,' Global Constitutionalism 8, No. 1 (2019): 140.

67 'Nearly half (49\%) of leave voters said the biggest single reason for wanting to leave the EU was »the principle that decisions about the UK should be taken in the UK «. One third (33\%) said the main reason was that leaving "offered the best chance for the UK to regain control over immigration and its own borders." "Lord Ashcroft, A reminder of how Britain voted in the EU referendum - and why, Lord Ashcroft Polls, March 15, 2019, See $<$ https://lordashcroftpolls.com/2019/03/a-reminder-of-how-britain-voted-in-the-eu-referendum-and-why/>.
} 
As demonstrated, two kinds of references to the protection of national identity can exist: those that violate the multiculturalist interpretation of the relationship between Article 2 and Article 4(2) and those that do not. Taking a critical stance against the EU when it comes to defining national identity can be perfectly acceptable (exercising sovereignty by making otherwise legitimate decisions). But the same act becomes impermissible when used to exert sovereignty to lower the level of protection for inclusive values.

The practice adopted by liberal multicultural federal states-especially the way it affects recognised territorial communities-could also help conceptualise the enforcement of Article 2 values. Quebec's Bill 101, the Charter of the French Language adopted in $1976^{68}$ provides a good example of what we call a clash between exclusive and inclusive values. The legislation limited the language rights of the province's Anglophone and Allophone population by declaring French the only official language (used by legislature, courts, government institutions, public schools, commerce and business sectors) and turned against the Canadian federal constitutional vision of the cultural mosaic. ${ }^{69}$ Among other restrictions, Bill 101 severely limited the possibility of English language instruction in the province. The central argument for this was the protection of the French language-inherent to the Quebec culture - against the domination of English.

The Supreme Court of Canada rendered several judgements on Quebec's Bill 101. In its first famous decision in Quebec v. Quebec Association of Protestant School Boards (1984), the Canadian Supreme Court ruled that the Bill's provision about French language instruction violated Section 23 of the Canadian Charter of Rights and Freedoms (1982). ${ }^{70}$ This section guarantees minority language educational rights to French-speaking citizens outside Quebec, and to English-speaking citizens in Quebec. However, because the scope of Section 23 is limited to Canadian citizens only (and mainly to those whose first language is English or French), immigrants and Allophones were not properly protected by the Charter of Rights and Freedoms against the exclusive aspirations of Quebec's legislation and policies.

The struggle continued. The Supreme Court's actions were often followed by further restrictive steps by Quebec, e.g., when the Charter of the French Language was amended by Bill 104 in 2002. This modification reacted to the practice that sought to circumvent the restrictions of the original Bill: Allophone children could gain access to English-language education in public schools after a brief English-language education at a private school ('bridging schools'). To further restrict the language rights of Allophone children, Section 3 of Bill 104 added the following to Section 73 of Bill 101: 'instruction received in English in Quebec in a private educational institution not accredited for the purposes of subsidies by the child for whom the request is made, or by a brother or sister of the child, shall be disregarded. ${ }^{71}$ In the Nguyen v. Quebec (2009) case $^{72}$ the Supreme Court of Canada declared that Bill 104 is

\footnotetext{
${ }^{68}$ Charter of the French Language, R.S.Q. ch. C-II (1977).

${ }^{69}$ See further in: Clifford Savren, 'Language Rights and Quebec Bill 101,' Case Western Reserve Journal of International Law 10, no. 2 (1978): 543-72; William Green, 'Language Regimes, Minority Language Rights, and International Legal Issues: The Case of Quebec Anglophones,' Syracuse Journal of International Law and Commerce 26, no. 2 (1999): 267-90.; RH, Canadian Language Wars (yet again), 1.CONnect - Blog of the International Journal of Constitutional Law, October 23, 2009, <http://www.iconnectblog.com/2009/10/canadian-language-wars-yet-again/>.

${ }^{70}$ Attorney Gen. Quebec v. Quebec Ass'n of Protestant Sch. Bds. [1984] 2 S.C.R. 66.

${ }^{71}$ Bill 104 (2002, chapter 28) An Act to amend the Charter of the French language. See

<http://www2. publicationsduquebec.gouv.qc.ca/dynamicSearch/telecharge. php?type=5\&file=2002C28A.PDF>

${ }^{72}$ Nguyen v. Quebec (Education, Recreation and Sports), [2009] 3 S.C.R. 208.
} 
unconstitutional because it infringes on minority language education rights. This series of cases demonstrates how a liberal polity can set principled limits on restrictive policies in a subentity that invokes existential challenges and identity arguments.

It might be apparent that the parallel with the EU is more defined when we examine recognised territorial units (i.e., autonomous areas or federated states) in constitutional democracies and probably even in the case of indigenous or other minority communities who control a given territory. It also remains true that compared to the EU, there are important differences: the state still seems to be the central locus of conducting politics and taking collective responsibility. That being said, debates on sovereignty and national identity in certain constitutional democracies liken these cases more to the EU than generally assumed, see, e.g., the (historical and contemporary) discussions on the status of states in the US. ${ }^{73}$ Crucially, the dilemma of recognising strong identity claims unites the two sets of cases. The EU is faced with diversity challenging some of its fundamental tenets, a key concern for multiculturalists considering responses to illiberalism. This is where our parallel is most incisive.

We have seen that Canada has been grappling with policing the boundaries of accommodation (not only with regard to Quebec, but also concerning its indigenous and immigrant populations), an experience that has led to the emergence of working standards. Kymlicka built a widely cited theory on the Canadian example, one which sets out straightforward principles for when liberal interference is justified. A similar elaboration for the EU is missing. In the next section, we revisit Kymlicka's normative framework to see what insights it offers for the illiberal challenge in Europe.

\section{Kymlicka's Account of Liberal Interference with Illiberal Minorities}

The central dilemma, shared by the multiculturalist and the supranationalist setting, is the point at which illiberal deviation should cease to be tolerated and when liberal interference is legitimate. Will Kymlicka addressed the problem of illiberal minorities in his 1995 book Multicultural Citizenship, an account that can help us operationalise the dilemma. ${ }^{74}$ Kymlicka lists the following points that should be considered when assessing the legitimacy of interference:

1) 'the severity of rights violations';

2) 'the degree of consensus within the community on the legitimacy of restricting individual rights';

3) 'the ability of dissenting group members to leave the community if they so desire';

4) 'the existence of historical agreements'.$^{75}$ (emphases added)

The severity argument sounds rather straightforward and would form part of any assessment of the legitimacy of interference. It is in fact a key part of Article 7 TEU itself ('serious breach'). What the multiculturalist approach helps to better capture is the protection of the liberal core,

\footnotetext{
${ }^{73}$ For an overview of the dilemma, see Timothy Zick, 'Are the States Sovereign?' Washington University Law Review 83, No. 1 (2005): 229-337.

74 This is an account that one of us discusses in more detail in a separate article. Zsolt Körtvélyesi, Illiberal Challenge in the EU: Exploring the Parallel with Illiberal Minorities through the Case of Hungary' under review at the European Constitutional Law Review.

${ }^{75}$ Will Kymlicka, Multicultural Citizenship (Clarendon, Oxford, 1995), 169-70.
} 
against which pluralism can play out. This is the moral equality underlying inclusive values, most importantly: democracy, the rule of law, and human rights. The more a legal regime manifests the wholescale rejection of this core (possibly leading to destructive pluralism), the more likely any liberal interference countering these tendencies will be justified. ${ }^{76}$ In the case of Hungary, measures that target opposition-held local governments, NGOs, academic institutions and individuals that are critical of the government, can be seen as violations of all three values.

Less obvious is the second consideration, on how wide the support for restrictions is. While this might feature as a hidden political motive when deciding on political action, it makes sense to give more leeway for deviations where these are sustained and deeply held commitments of the community, shared by most, as opposed to forged and momentary preferences seeking exemptions for gains by the elite. Deciding what counts as sincere, consensual conviction in a society is no easy task. (It seems no less paradoxical than trying to assess the genuineness of religious views, a move often considered intrusive in the process of testing the legitimacy of intrusion.) For example, in a less-than-democratic society, the government's sustained efforts to curtail media pluralism can raise suspicions in this respect. In the Hungarian case, these were the first series of measures that raised international attention related to regulating the media. That was also the case that inspired the reverse Solange proposal.

Third is the exit option. On one level, this could be read as a requirement that citizens (residents) should be able to leave the country and as such its restrictions behind. Such moves always have costs but are certainly available, as seen above. In fact, with the most dissatisfied members of the community leaving, ${ }^{77}$ this option can end up reinforcing internal cohesion and consensus around the restrictions (point 2 above). Raz rightly notes that a multicultural setting can strengthen restrictive traces. ${ }^{78}$ In Kymlicka's view, if people are free to leave the community, more pressing arguments are needed to interfere with oppressive practices. This might mean the physical aspect of opting out, now guaranteed under free movement rules. (In fact, hundreds of thousands of Hungarians have been making use of this right when they have opted to live in other EU Member States. ${ }^{79}$ ) It can also refer to the ability of residents (especially in the case of a state) to be able to leave the cultural community, meaning the majority as envisioned in public law norms, including the constitution. And the costs of this choice should not be prohibitive.

The exit option can also be applied on another level: if a group is more justified in asking for adherence to its common values when members are free to leave, this should apply equally (or even more strongly) to the EU. Member States are free to leave if they disagree over key

\footnotetext{
${ }^{76}$ To illustrate the difference between exclusive elements that can be recognised and those that undermine the core, there is a crucial difference between affirmative measures (like Art. 116 of the German Grundgezetz) and a wholesale ethnicisation and exclusion (see, e.g., the recent 'National State Law' of Israel, read summary here: <https://www.jpost.com/Israel-News/Read-the-full-Jewish-Nation-State-Law-562923)>.

77 On the phenomenon and related choices, see Albert O. Hirschman's classic from 1970 'Exit, Voice, and Loyalty'. Albert O. Hirschman, Exit, Voice, and Loyalty. Responses to Decline in Firms, Organizations, and States. (Harvard University Press, Cambridge, 1970).

78 ' $[E] x i s t e n c e$ in a multicultural society often makes cultural groups more repressive than they would be were they to exist in relative isolation.' Raz, 'Multiculturalism...,' 185.

79 Irén Gödri, Nemzetközi vándorlás [International migration], in Demográfiai portré 2015 [Demographic Portrait 2015], eds. Judit Monostori, Péter Őri, and Zsolt Spéder (KSH [Central Statistics Office], 2015), 187-211, at 188.
} 
elements of cooperation. Depending on how prohibitive the terms of leaving are (see the Brexit saga), this can tilt the field toward more or less legitimate expectations of members.

Fourth, Kymlicka states that what arrangements have governed the relations of the two entities in question - the EU and its Member State in our case-should matter. For example, new Member States by and large joined the EU under the current rules, including the 'depth' of integration and Article 2 values. Countries like the UK, on the other hand, could voice their opposition throughout the deepening of the integration and the process of encompassing political aspects in addition to economic issues.

There is a fifth consideration that Kymlicka discusses outside his original typology, namely the 'newcomers' argument. According to Kymlicka, pressures for change are more legitimate when applied to newly arriving immigrant groups. ${ }^{80}$ We connect this to the fourth element, as the fact of new arrival can be taken as a different type of arrangement. Applied to the EU, this would mean measures like the Cooperation and Verification Mechanism, as an added layer of conditionality, post-accession, for 'newcomers' Bulgaria and Romania.

Beyond the list above, Kymlicka also discusses ways of responding to violations. He advises speaking out against them, supporting those who can help overcome them, and creating incentives for leaving them behind, including stronger guarantees of human rights. ${ }^{81}$ The latter, he says, is a means of possible liberal interference without hard sanctions-the type Raz also favours when available.

What follows from this for the EU? The legitimacy of interference with illiberal regimes depends on a number of factors. The most uncontroversial will be the severity of the violations. Kymlicka also suggests taking into account the level of domestic support for restrictions and the ability of group members to opt out (the exit option on the level of the individual). Both underline the importance of democratic will-formation at the domestic level and room for dissent. If pluralism suffers because opt-out from illiberalism is too costly, e.g., one has to leave physically or is targeted or even pushed out for being considered disloyal to the regime ('traitors of the nation'), claiming democratic legitimacy will become problematic. The legitimacy of liberal interference is supported by two further aspects: accession to and participation in the EU (consent) where leaving is an available option (the exit option on the level of member states). In our view, the most problematic element of Kymlicka's framework is this differentiation based on the length of membership. Choudhry questions the grounds for the distinction because the community-based arguments that apply to national and

\footnotetext{
80 'Cases involving newly arriving immigrant groups are very different.' Kymlicka, Multicultural Citizenship, 170. Cf. 'A more complicated case involves long-standing ethnic groups or religious sects who have been allowed to maintain certain illiberal institutions for many years, even many generations. [...] For various reasons, when these immigrant groups arrived, they were given exemptions from the usual requirements regarding integration, and were allowed to maintain certain internal restrictions.' Ibid.

81 'There are many ways to strengthen mechanisms for respecting individual rights in a consensual way, without simply imposing liberal values on national minorities.' Kymlicka, Multicultural Citizenship, 169. The fact that the majority group cannot intervene in a coercive manner 'does not mean that liberals should stand by and do nothing. A national minority which rules in an illiberal way acts unjustly. Liberals have a right, and a responsibility, to speak out against such injustice. Hence liberal reformers inside the culture should seek to promote their liberal principles, through reason or example, and liberals outside should lend their support to any efforts the group makes to liberalize their culture. Since the most enduring forms of liberalization are those that result from internal reform, the primary focus for liberals outside the group should be to provide this sort of support.' Ibid. at 168. E.g., 'liberals can push for the development and strengthening of international mechanisms for protecting human rights.' Ibid. at 169.
} 
indigenous groups seem applicable to immigrant communities, and hence normative distinction is incoherent. ${ }^{82}$ The problem of double standards is even more problematic in the case of EU Member States: if we want to interfere on liberal multiculturalist grounds, strong and consistent reasons should be provided. In the EU, distinctions between old member states and newcomers would undermine the legitimacy of liberal interference. How could sanctions in the name of inclusive values rest on rules that single out, exclusively, some states only because they joined later? The lost sense of fairness could undercut the effectiveness of the entire framework.

More considerations and examples could be added, but this brief overview should suffice to illustrate how insights from multiculturalist theories can help us conceptualise and operationalise the question of legitimate interference in cases of oppressive measures.

\section{Conclusions}

In this article we proposed the application of theories of liberal multiculturalism as a normative background theory in addressing the dilemma raised by the anti-constitutionalist challenge in the European Union. This normative framework could help protect liberal democracy within Member States and on the EU level alike. To conduct this analysis, we argue that it is possible to compare the challenge of illiberal Member States in the European Union to the problem of illiberal policies and legislations of federated states in liberal multicultural federal states. We believe that this approach and the lessons learnt from how liberal multicultural states function can enrich the debate on constitutional pluralism with a clear focus on the recognition of cultural communities. It could also help conceptualise the enforcement of Article 2 TEU values and interpret its relationship to the protection of national identities as cited by Article 4(2) as well as the assessments under Article 7 TEU in a way that supports inclusive constitutional values.

Relying on this multiculturalist account, we can judge not only the main challenges in the EU (e.g., Brexit, or the Hungarian public law crises), but also the justifiability of different Member State arguments, policies and legislations regarding the protection of their national identities. These arguments, policies and legislations range from the UK's defending parliamentary supremacy against Europe to populist governments aiming to protect national identity from humanitarian and human rights NGOs.

The multiculturalist approach helps us identify key elements of the balancing exercise, including the severity of the violations measured against core commitments; the level of domestic support (in cases where public discourse is still open, plural, and democratic); the costs of both physically and 'culturally' opting out of the community (compared to the costs of the country leaving the EU); and finally the possible history of reservations and good-faith attempts at renegotiating the terms of membership. The multiculturalist framework suggests that in terms of the means applied by liberal interference, methods that least curtail pluralism are preferred over harsher measures.

\footnotetext{
82 Sujit Choudhry, 'National minorities and ethnic immigrants: Liberalism's political sociology,' Journal of Political Philosophy 10 (2002): 54-78.
} 


\section{Acknowledgements:}

The authors would like to thank comments from the participants of the Global Constitutionalism Scholars Workshop ('New Thinking in Global Constitutionalism') at the WZB Berlin Social Science Center, on July 6, 2019, especially the two commentators, Andreas Føllesdal and Mattias Kumm.

This article was conducted within the scope of the $\mathrm{H} 2020$ project Democratic Efficacy and the Varieties of Populism in Europe (DEMOS) and was funded by the European Commission under the Grant agreement 822590 . Any dissemination of results here presented reflects only the authors' views. The Agency is not responsible for any use that may be made of the information it contains. 